\title{
Auto-training influence on cadets' functional state during airborne training
}

\author{
Oleg V. Labeshchenkov* \\ Proshlyakov Higher Military-Engineering Command College (Military Institute), Tyumen, \\ Russia \\ Labeshenkova@yandex.ru*
}

\begin{abstract}
The article considers the questions and problems of airborne training improvement among cadets of engineering profile using auto-training methodology. Methodology includes a complex of exercises, directed toward cadets' psychological tension decrease before and after parachute jumps. Materials. The article presents the results of the experimental research concerning the effectiveness of auto-trainings methodology substantiation in terms of cadets' training sessions. Taking into consideration the influence of great physical, psychic and emotional loads and the tendency of their increase in the macrocycle of cadets military- assault training and special demands imposed on functional state of an organism, we define the necessity to include auto-trainings into the training process. Research methods. Information sources and documents analysis, questionnaire survey, control tests, mathematical-statistical analysis of results. Results. We created and preliminarily experimentally substantiated auto-trainings methodology for cadets during military- assault training. Auto-training methodology includes audio-sessions use according to M.A. Bendyukov methodology before and after trainings in different composition (soothing variant of audio-sessions). The methodology also includes five exercises, directed toward psyche switching-off owing to attention switching and switching off and muscles relaxation together with respiration. The received results were handled with the help of nonparametric method. The received results comparison showed that after jumping training cadets from the experimental group had physical working capacity decrease. 30 minutes after the methodology of auto-training application we revealed physical working capacity increase in the experimental group. In the control group we revealed further working capacity decrease, which characterizes fatigue. The same dynamics was in energetic indices, such as the volume of muscular activity anaerobic source energy supply, the volume of muscular activity aerobic source energy supply, general metabolic volume of an organism, aerobic and anaerobic organism propensity, power of muscular activity creatine phosphate source energy supply, aerobic source of energy supply power; heart rate (pulse) at the abilities level of an organism (threshold of anaerobic metabolism (TANM) pulse). Conclusion. The results of the experiment showed that systematic use of auto-trainings helps to cope with tiredness and working capacity level decrease owing to recovery processes in an organism improvement with psychic component inclusion.
\end{abstract}

Keywords: cadets, airborne training, methodology, auto-trainings, results.

For citation: Oleg V. Labeshchenkov. Auto-trainings influence on cadets' functional state during airborne training. The Russian Journal of Physical Education and Sport. 2018; 13 (4): 72-77. DOI 10.14526/20704798-2018-13-4-87-94

Considerable loads in sport and also in airborne training of engineering profile cadets very often cause physical and emotional overloads of an organism and it leads to cadets' physical working capacity decrease $[1,2,3,4,5,7]$. The reason for this phenomenon can be unpreparedness of cadets to fulfill maximum loads and insufficient use of working capacity renewal means [10]. In the opinion of many authors, one of the most effective means of physical and emotional tension decrease can be auto-training, directed toward cadets' different adaptive reactions regulation [9,11,12].

The results of the pedagogical observation showed that airborne training imposes great demands not only on physical, but also on cadets' psychic training. It is connected, first of all, with great functional loads during airborne training, which demand cadets' maximum physical tension, the whole organism activity, his functional physiological systems intensification. Many authors mention that a lot of factors influence the dynamics of cadets' psychic state before a parachute jump [8,13,14].

Modern airborne training (AT) development demands effective and dynamic realization of the 
ability to react to all factors of the action and it causes additional psychic difficulties before parachute jumping [15].

During the pedagogical observation it was revealed that the main characteristics of AT are the following: considerable physical, psychic and emotional loads increase and the tendency to their increase in a macrocycle of training.

AT planning among cadets of engineering profile wasn't considered in practice with the use of autotrainings. In our opinion, such kind of trainings inclusion into the training will help to solve some problems of tension decrease among cadets during AT. Such kind of tension can appear in terms of insufficient psychic maturity, steadiness, readiness before the jump.

\section{Material and Methods}

The following complex of research methods was used in the research: information sources and documents analysis, questionnaire survey, control tests, mathematical-statistical analysis of results.

We held the research at Tyumen Higher Military-Engineering Command College (military Institute) named after marshal of engineers corps A.I. Proshlyakov. The cadets of the $1^{\text {st }}$ course took part in the experimental work (age range: 17-19 years old).

The aim of the research was to define the influence of auto-training on functional indices of engineering profile cadets during AT in terms of preliminary research works.

Information sources analysis, devoted to auto-trainings inclusion in kinds of sport, helped to make the problem of AT negative influence on cadets' psycho-emotional sphere development urgent.

A questionnaire survey among cadets $(n=23)$ after the first jump with a parachute showed overtension (34\%) and insufficient physical working capacity recovery (66\%). In this case it is necessary to use the means of cadets' psycho-emotional status regulation. Mastering the method of auto-training gives great opportunities for the problem solution.

The respondents, cadets-specialists in AT ( $\mathrm{n}=25)$, underlined that AT effectiveness (56\%) and jumps fulfillment effectiveness (44\%) mainly depend on psychic state of cadets (100\%). They also mention that if cadets are in a good mood before the jump and have the sense of sports excitement, anger or inspiration, the results of the jump will be at a high level. If cadets are silent, experience apathy, have low working capacity level, if they are upset, not sure, they have a low level of motor actions control.

That is why specialists think it is necessary to teach cadets regulate own psychic state during physical and psychic loads.

It is necessary to include auto-trainings into AT process of engineering profile cadets, directed toward an optimal combatant psychic state formation, which broadens the opportunity of psycho-physical qualities realization.

Auto-trainings inclusion into the process of sports training showed, that it provides the range of respondent's abilities broadening concerning current state control, including the cases when it is necessary to stop the symptoms of stress situations and general dynamics of a functional state change $[8,9]$.

The skill of auto-training use will help cadets not only to stop or prevent different unfavorable states development, but also form own necessary state, for example, combat readiness, concentration and complete readiness for action.

Nowadays an impressive amount of the applied teaching programs of psychological self-regulation are created. They are based on different methods. Publications analysis shows that the research works results prove the effect of a functional state optimization regardless of the used psychological self-regulation program type. Thus, we come to the conclusion that auto-trainings are useful for cadets during AT.

\section{Results and Discussion}

Auto-training methodology during AT included audio-sessions use, according to M.A. Bendyukov 
methodology, before and after the trainings. At the end of the training lessons a soothing variant of audiosessions was used in order to activate rehabilitation processes and neuropsychiatric rehabilitation. The duration of audio-sessions was 5-20 minutes. Sessions can be listened to within 30 minutes before AT.

The effectiveness of teaching auto-training techniques with the help of video-sessions of states selfregulation increases, if they are used regularly 2-3 times a week after intensive training loads in order to recover working capacity and psycho-emotional state.

Table 1 presents the exercises, directed toward psychic switching off, in terms of auto-training methodology for cadets.

Table 1 - The content and conditions for exercises realization, directed toward cadets' psychic switching off during the process of airborne training

\begin{tabular}{|c|c|c|c|}
\hline № & $\begin{array}{l}\text { Entitlements and } \\
\text { directions of the } \\
\text { exercise }\end{array}$ & Content of the exercise & Conditions of realization \\
\hline 1 & $\begin{array}{l}\text { A t t e n t i o n } \\
\text { d e e lo ping } \\
\text { exercises }\end{array}$ & $\begin{array}{l}\text { Start position: take a stopwatch } \\
\text { and follow the movement of a } \\
\text { second's hand, focusing attention } \\
\text { only on it, as long as possible. }\end{array}$ & $\begin{array}{l}\text { Defining the longest time period, within } \\
\text { which it was possible to focus attention } \\
\text { on a second's hand, a person should try to } \\
\text { repeat the periods of the same attention } \\
\text { focusing } 3-4 \text { times successively, making } \\
\text { pauses between each attempt 10-20 } \\
\text { seconds. }\end{array}$ \\
\hline 2 & $\begin{array}{l}\mathrm{T} \quad \mathrm{h} \quad \mathrm{i} \quad \mathrm{n} \quad \mathrm{g} \quad \mathrm{s} \\
\mathrm{r} \text { e m e m b e r in } \mathrm{g} \\
\text { exercises }\end{array}$ & $\begin{array}{l}\text { Start position: to examine some } \\
\text { object attentively, then close } \\
\text { one's eyers and picture it in all } \\
\text { details. }\end{array}$ & $\begin{array}{l}\text { After that look at this thing one more time } \\
\text { and check if one's viewing corresponds } \\
\text { with the real object. }\end{array}$ \\
\hline 3 & $\begin{array}{l}\text { Attention focusing } \\
\text { on breathing } \\
\text { exercises }\end{array}$ & $\begin{array}{l}\text { Start position: examine the } \\
\text { object and take a slow breath, } \\
\text { as if trying to take this object } \\
\text { into one's brains, memory. Then } \\
\text { making a slow outward breath } \\
\text { close the eyes and mentally } \\
\text { reproduce the image of the object } \\
\text { or a phenomenon that you have } \\
\text { just seen. }\end{array}$ & $\begin{array}{l}\text { Very often during focusing attention } \\
\text { appears psychic tension (facial muscles } \\
\text { contraction, frown eyebrows, set mouth, } \\
\text { which causes other muscles involuntary } \\
\text { tension), in sports practice such tension } \\
\text { does only harm. In sports activity it is } \\
\text { very important to fulfill a lot of things, } \\
\text { including the ability to focus on things } \\
\text { without tension. }\end{array}$ \\
\hline 4 & $\begin{array}{l}\text { Exercises for } \\
\text { attention focusing } \\
\text { on breathing }\end{array}$ & $\begin{array}{l}\text { Start position: examining an } \\
\text { object make an exhalation longer } \\
\text { than an inhalation. It is known } \\
\text { that an inhalation phase is a } \\
\text { mobilizing one and exhalation } \\
\text { phase is a relaxing one. If a cadet } \\
\text { needs relaxation, we recommend } \\
\text { to fulfill several long exhalations } \\
\text { after a short energetic inhalation } \\
\text { and then goes a short pause - } \\
\text { breath holding. }\end{array}$ & $\begin{array}{l}\text { In this case it is necessary to use abdominal } \\
\text { or diaphragmatic breathing, when during } \\
\text { the inhalation abdomen is thrown out and } \\
\text { during exhalation abdomen is pulled in, } \\
\text { pushing air out of lungs. } \\
\text { Inhalation on two, exhalation on four, } \\
\text { pause-on two. If it is necessary to mobilize } \\
\text { and activate oneself, we recommend } \\
\text { the following: realize breathing making } \\
\text { inhalation longer till four, make a pause } \\
\text { till } 2 \text { and quick inhalation till two. During } \\
\text { inhalation it is necessary to tense muscles } \\
\text { (hands and legs) not to one's full capacity. } \\
\text { During exhalation relax them and percept } \\
\text { the appearing feelings. }\end{array}$ \\
\hline
\end{tabular}




\begin{tabular}{|c|c|c|c|}
\hline 5 & $\begin{array}{l}\text { Exercises } \\
\text { tension } \\
\text { relaxation }\end{array}$ & $\begin{array}{l}\text { Start position - standing, feet } \\
\text { apart; "one" - deep breath, } \\
\text { hands up-hands to the sides, } \\
\text { fingers extended, give a stretch; } \\
\text { "two" - tense muscles of the } \\
\text { whole body, hold one's breath, } \\
\text { "three-four-five"- keep tension } \\
\text { and hold one's breath, attention } \\
\text { in focused on muscles tension } \\
\text { perception (in turn: arms, neck, } \\
\text { chest, back, abdomen, hips, } \\
\text { shin); on command "all" - limply } \\
\text { take the position of a low crouch, } \\
\text { head down; }\end{array}$ & $\begin{array}{l}\text { In turn tensing and relaxing different } \\
\text { groups of muscles, gradual and } \\
\text { differentiated muscles relaxation, tensing } \\
\text { one group of muscles and simultaneously } \\
\text { relaxing others, different rhythmic and } \\
\text { breathing exercises. } \\
\text { 2-3 times make a full breath and full } \\
\text { exhalation; then several inhalations and } \\
\text { extended exhalations, focusing attention } \\
\text { on exhalation and more complete muscles } \\
\text { relaxation. On command: "get up, relax } \\
\text { muscles more" get up, fulfill several } \\
\text { jumps for better muscles relaxation, then } \\
\text { massage the muscles, focusing attention } \\
\text { on their deeper relaxation. }\end{array}$ \\
\hline 6 & $\begin{array}{l}\text { Audio-session } \\
\text { exercises }\end{array}$ & $\begin{array}{l}\text { At the end of the training lessons } \\
\text { relaxing variant of audio- } \\
\text { sessions were used. }\end{array}$ & $\begin{array}{l}\text { Audio-sessions are directed toward } \\
\text { rehabilitation processes activation, } \\
\text { neuropsychiatric rehabilitation. } \\
\text { The duration was from } 5 \text { to } 20 \text { minutes } 30 \\
\text { minutes before AT. }\end{array}$ \\
\hline
\end{tabular}

Presented above exercises were realized before pre-jump assault training and after jumping training. Exercises repletion was realized taking into account cadets' operative state, which was determined during the conversation before the jumping training. All presented exercises, including audio-sessions, formed the content of the experimental audio-training methodology.

Taking into account the urgency of chosen by us problem of auto-training use in AT practice of firstyear cadets. The effectiveness was determined taking into account functional indices, which characterize functional state and reserve capacities of an organism. For this purpose we defined the indices according to "D\&K" before and after auto-training methodology use. The research was held in terms of educationaltraining camp. The following indices were studied: anaerobic metabolic capacity (the capacity of anaerobic source of muscular activity energy supply), which characterizes the ability to fulfill intensive physical and other types of loads at maximum organism abilities, mainly of anaerobic orientation; aerobic metabolic capacity (the capacity of aerobic source of muscular activity energy supply), which characterizes the ability to fulfill long-term physical and other loads, mainly of aerobic orientation; general metabolic capacity of an organism, characterizing genetically predicted level of organism capacities (legal competence and working capacity) and the ability to fulfill general amount of physical and other types of loads; aerobic propensity of an organism, which reflects aerobic genotype of an organism, determines processes of rehabilitation during intellectual, physical and other types of aerobic orientation loads fulfillment, predetermines propensity for digestive tract diseases, cold, traumatism, determines introvertivity and irrationality, provides an individual's professional inclinations determination; power of creatine phosphate source of muscular activity energy supply, which determines the level of irascibility, reactivity, power endurance; power of muscular activity glycolytic source energy supply, which determines reproductive and utilization functions of liver, the level of speed endurance; power of an organism (maximum oxygen consumption) aerobic source of muscular activity energy supply, which determines the quality of the fulfilled physical load till TANM level; genetically predetermined heart rate (pulse) at the organism capacities level, effectiveness criterion of muscular activity aerobic source energy supply (TANM pulse), which determines pulse limits of different physical loads intensity zones.

Table 2 presents the dynamics of cadets' organism functional state indices before and after autotraining use during airborne training. 
Table 2 - Dynamics of cadets' organism functional state indices before and after auto-training use

\begin{tabular}{|c|c|c|c|c|c|c|c|}
\hline Indices & \multicolumn{3}{|c|}{ Experimental group (Xav) } & \multicolumn{3}{c|}{ Control group (Xav) } \\
\hline & $\begin{array}{c}\text { Before } \\
\text { the } \\
\text { lessons }\end{array}$ & $\begin{array}{c}\text { After the } \\
\text { lessons }\end{array}$ & $\begin{array}{c}\text { After 30 } \\
\text { minutes of } \\
\text { rest }\end{array}$ & $\begin{array}{c}\text { After auto- } \\
\text { training use }\end{array}$ & $\begin{array}{c}\text { Before } \\
\text { the } \\
\text { lessons }\end{array}$ & $\begin{array}{c}\text { After } \\
\text { the } \\
\text { lessons }\end{array}$ & $\begin{array}{c}\text { After 30 } \\
\text { minutes of } \\
\text { rest }\end{array}$ \\
\hline $\begin{array}{c}\text { PWC } \\
\text { 170, } \\
\text { min }\end{array}$ & 1200 & 1050 & 1030 & 1250 & 1210 & 1035 & 1030 \\
\hline MOC, ml & 3102 & 3100 & 3120 & 3250 & 3100 & 3080 & 3070 \\
\hline ANAMC, c.u. & 69,34 & 72,34 & 80,41 & 84,34 & 68,34 & 72,17 & 73,21 \\
\hline AMC, c.u. & 240,45 & 245,45 & 260,45 & 270,34 & 241,23 & 261,23 & 251,23 \\
\hline GMC, c.u. & 309,27 & 319,37 & 320,67 & 321,47 & 303,23 & 304,34 & 302,56 \\
\hline PCP, c.u. & 28,76 & 30,34 & 30,45 & 40,34 & 27,76 & 29,54 & 29,35 \\
\hline PGL, c.u. & 33,12 & 34,22 & 37,09 & 40,13 & 32,45 & 31,34 & 30,45 \\
\hline HR tanm & 158,56 & 158,56 & 156,74 & - & 154,34 & 143,56 & - \\
\hline HR,beats/min & 72 & 86 & 72 & 68 & 74 & 80 & 78 \\
\hline
\end{tabular}

Note: $\mathrm{PWC}_{170}$ - physical working capacity; MOC - power of aerobic source of energy supply (maximum oxygen consumption); ANAMC - anaerobic metabolic capacity; AMC - aerobic metabolic capacity; GMC - general metabolic capacity of an organism; PCP - power of creatine phosphate source of muscular activity energy supply; PGL- power of energy supply glycolytic source; HR on TANM-heart rate (pulse) tanm

The research was held before and after AT and after 30 minutes of rest. During 10 minutes autotraining was held for the experimental group, for the control group passive rest was organized. The received results were handled with the help of nonparametric method. The received results comparison showed that after jumping training cadets from the EG had physical working capacity decrease from $1200 \mathrm{~kg} / \mathrm{m} / \mathrm{min}$ till $1050 \mathrm{~kg} / \mathrm{m} / \mathrm{min}$. 30 minutes after auto-training methodology use we stated physical working capacity increase in the EG. In the CG with the initial values of physical working capacity $1150 \mathrm{~kg} / \mathrm{m} / \mathrm{min}$ and 1130 $\mathrm{kg} / \mathrm{m} / \mathrm{min}$ we stated its further decrease till $1112 \mathrm{~kg} / \mathrm{m} / \mathrm{min}$, characterizing the state of fatigue. The same dynamics was in MOC indices in the experimental groups, where a stimulating HR tanm threshold level increase was revealed.

There was a multidirectional dynamics in functional indices, which characterize energetic processes in cadets' organisms.

In the indices of muscular activity anaerobic metabolic capacity energy supply source, characterizing the ability to fulfill intensive physical and other loads at the limit of organism capacities (mainly of anaerobic orientation) cadets from the EG had a positive dynamics and rehabilitation after auto-training. In the CG cadets had power decrease.

Aerobic metabolic capacity, characterizing the ability to fulfill long-term physical and other loads (mainly of aerobic orientation), increased among cadets from the EG and was the index of aerobic metabolic capacity range broadening. The same situation was in general metabolic capacity indices of an organism, which characterized the ability to fulfill general amount of physical and other types of loads.

PCP and PGL indices among cadets from EG increased, characterizing the level of reactivity, power endurance, explosive power increase and preservation and the level of speed endurance improvement. In the indices of heart rate (pulse) at the level of organism capacities the effectiveness increase of aerobic source of muscular activity energy supply was stated among cadets from the EG.

\section{Conclusion}

Thus, the results of the experiment showed that systematic use of auto-trainings helps to cope with tiredness and working capacity level decrease owing to recovery processes in an organism improvement with psychic component inclusion. We revealed the tendency of muscular activity power increase energy supply owing to rehabilitation processes of central nervous system intensification. 


\section{References}

1. Borodin V.V., Ermolaeva V.I. Physical training in sport influence on military men's psychological steadiness formation. Aktualnye problem gumanitarnykh I sotsialno-ekonomicheskikh nauk. 2014; 3: 66-72 (in Russ.).

2. Kuznetsova Z.M., Ryabchuk A.V., Labeshchenkov O.V. Theoretical and practical aspects of airborne training individualization among cadets of engineering profile. Pedagogiko-psikhologicheskie $i$ medico-biologicheskie problem fizicheskoy kultury i sporta = The Russian Journal of Physical Education and Sport. 2018; 13(2): 198-206. DOI: 10.14526/o2_2018_326 (in Russ., in Engl.).

3. Dushanin S.A., Beregovoy Yu.V., Miguleva V.G. Intensivnye metody izucheniya energeticheskogo metabolizma myshechnoj aktivnosti [Intensive methods of muscular activity energetic metabolism study: Methodical recommendations]. Kiev. 1984: 27.

4. Nikityuk M.V. Theoretical substantiation of the methodology of training Greco-Roman style wrestlers taking into consideration their bioenergetics profile. Pedagogiko-psikhologicheskie i medicobiologicheskie problem fizicheskoy kultury i sporta = Pedagogico-psychological and medico-biological problems of physical culture and sport. 2014; 4(32): 47-53. URL: http://www.journal-science.org/ru/ magazine/9.html.

5. Ponimaew O. E. Universal physical training in the concept of differentiated formation of physical readiness / O. E. Poymanov, Y. Y. Lobanov // Innovation science : the past, present, and future : collection of articles]. scientific.- prakt. Conf. (3 June 2016). - Ufa, 2016. - P.153-155.

6. Semenova E. V. on the formation of professional and moral stability in the cadets of the Ministry of internal Affairs of Russia / E. V. Semenova / / Bulletin of the Barnaul law Institute of the Ministry of internal Affairs of Russia. - 2010. - № 19. - Pp. 140-145.

7. Timofeyev D. A. the Functional status of servicemen with different level of neuropsychic sustainability in the context of activities related to high neuro-mental tension / D. A. Timofeev, V. V. Pakhomov // Bulletin of Saratov state agrarian University im. N. I. Vavilov. - 2007. - № 3. - P. 93-96.

8. Bosquet L., Gamelin F.-X., Berthoin S. Is aerobic endurance a determinant of cardiac autonomic regulation? European Journal of Applied Physiology. 2007; 100(3): 363-369. DOI: 10.1007/ s00421-007-0438-3.

9. Boutcher S.H., Park Y., Dunn S.L., Boutcher Y.N. The relationship between cardiac autonomic function and maximal oxygen uptake response to high-intensity intermittent-exercise training. Journal of Sports Sciences. 2013; 31(9): 1024-1029. DOI: 10.1080/02640414.2012.762984.

10. Bragada J.A., Santos P.J., Maia J.A., Colaco P.J., Lopes V.P., Barbosa T.M. Longitudinal study in $3000 \mathrm{~m}$ male runners: Relationship between performance and selected physiological parameters. Journal of Sports Sciences and Medicine. 2010; 9: 439-444. URL: http://www.jssm.org/vo19/n3/12/ v9n3-12pdf.pdf.

11. di Prampero P.E. The energy cost of human locomotion on land and in water. International journal of Sports Medicine. 1986; 7(02): 55-72. DOI: 10.1055/s-2008-1025736.

12. Foster $\mathrm{C}$. Monitoring training in athletes with reference to overtraining syndrome. Medicine and Science in Sports and Exercise. 1998; 30(7): 1164-1168. DOI: 10.1097/00005768-199807000-00023.

13. Ingham S.A., Fudge B.W., Pringle J.S. Training distribution, physiological profile, and performance for a male international 1500-m runner. International Journal of Sports Physiology and Performance. 2012; 7(2): 193-195.

14. Manzi V., Castagna C., Padua E., Lombardo M., D’Ottavio S., Massaro M., ..., Iellamo F. Doseresponse relationship of autonomic nervous system responses to individualized training impulse in marathon runners. AJP: Heart and Circulatory Pgysiology. 2009a; 296(6): H1733-H1740. DOI: 10.1152/ ajpheart.00054.2009.

15. Marcora S.M., Staiano W., Manning V. Mental fatigue impairs physical performance in humans. Journal of Applied Physiology. 2009; 106(3): 857-864. DOI: 10.1152/japplphysiol.91324.2008.

\section{Submitted: 01.11.2018}

Author's information:

Oleg V. Labeshchenkov * - senior teacher, Proshlaykov Higher Military-Engineering Command College (Military Institute), Tyumen, Russia, 625001, L. Tolstoy str., House 1 (10 military town), e-mail: Labeshenkova@yandex.ru* 